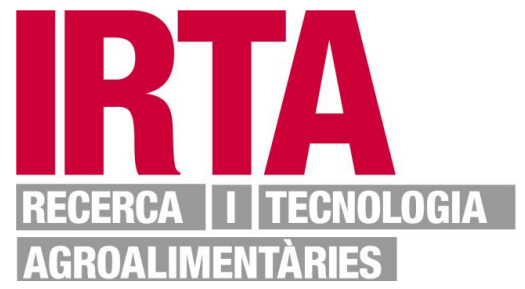

This document is a prepint version of an article published in Separation and Purification Technology (c) Elsevier. To access the final edited and published work see https://doi.org/10.1016/j.seppur.2019.116439

Document downloaded from:

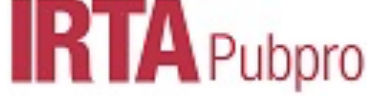

Open digital archive 


\section{Highlights}

Reliability of pollution removal in one-stage CWs of HF type in different seasons during longterm operation was analyzed

One-stage CWs don't provide stable and reliable of pollution removal in different seasons The lowest reliability of the pollutants removal (especially nitrogen and phosphorus) were usually obtained in winter and spring

One-stage CWs of HF type should not be recommended for wider use in temperate climate conditions. 


\title{
Technological reliability of pollutant removal in different seasons in one-stage constructed wetland system with horizontal flow operating in the moderate climate
}

\author{
Krzysztof Jóźwiakowskia ${ }^{*}$, Piotr Bugajski ${ }^{b}$, Karolina Kurek ${ }^{\mathrm{b}}$, Rafaela Cáceres ${ }^{\mathrm{c}}$, \\ Tadeusz Siwiec ${ }^{d}$, Andrzej Jucherski ${ }^{\mathrm{e}}$, Wojciech Czekała ${ }^{\mathrm{f}}$, Kamil Kozłowski ${ }^{\mathrm{f}}$
}

${ }^{a}$ Department of Environmental Engineering and Geodesy, University of Life Sciences in Lublin, Leszczyńskiego St. 7, 20-069, Lublin, Poland

${ }^{b}$ Department of Sanitary Engineering and Water Management, University of Agriculture in Kraków, Al. Mickiewicza St. 24/28 30-059 Kraków, Poland

${ }^{c}$ GIRO, , Institute of Research and Technology, Food and Agriculture (IRTA), Torre Marimon

Center, E-08140, Caldes de Montbui, Barcelona, Catalonia, Spain

${ }^{d}$ Department of Civil Engineering, Warsaw University of Life Sciences, Nowoursynowska St. 166, 02-787 Warszawa, Poland

${ }^{e}$ Mountain Centre of Research and Implementations in Tylicz, Institute of Technology and Life Sciences in Falenty, Pułaskiego St. 25A, 33-383 Tylicz, POLAND

Institute of Biosystems Engineering, Poznan University of Life Sciences, Wojska Polskiego 50, 60-637 Poznań,Poland

*Corresponding author: krzysztof.jozwiakowski@,up.lublin.pl

\begin{abstract}
The aim of this work was to determine the technological reliability of pollutions removal in different seasons in one-stage constructed wetland system with horizontal flow operating in the conditions of moderate climate. In the above-mentioned system, willow (Salix Viminalis L.) was planted and the average flow of domestic sewage were $1.2 \mathrm{~m}^{3} / \mathrm{d}$. The analyzed system is located in south-eastern Poland, where the climate is moderate transitional. The tests were carried out during the 14-year exploitation of the wastewater treatment plant (1997-2010). During this period, sewage samples were collected in 4 seasons (winter - February, spring may, summer - August and autumn - November) to be analyzed. The average long-term air temperatures in these months were: $-1.8 ; 13.8 ; 18.3$ and $3.5^{\circ} \mathrm{C}$. Altogether 56 series of analyzes were carried out during the research and 112 samples of the sewage, both from the inflow and the outflow of the wastewater treatment plant, were collected. The measured parameters were: $\mathrm{BOD}_{5}, \mathrm{COD}$, total nitrogen, total phosphorus. On the grounds of the reliability analysis performed on the basis of the Weibull probability model, it was found that the reliability of pollutions removal in the tested constructed wetland system are higher in summer and autumn (August, November) than in winter and in spring (February, May). It was shown that exceedance of the admissible values of pollutant indicators in treated wastewater is dependent on the season (air temperature) and it occurred mainly in the winter period (February). It was proved that the tested $\mathrm{CW}$ does not provide effective elimination of biogenic indicators (nitrogen and phosphorus), as evidenced by small values of reliability. To increase the technological reliability of the tested treatment plant, it is proposed to expand the existing system and create a hybrid system consisting of two beds with vertical and horizontal flow and a special P-filter.
\end{abstract}

Keywords: Weibull reliability method, pollutions removal; wastewater treatment; one-stage constructed wetland, moderate climate 


\section{Introduction}

In recent years in Poland and worldwide, household wastewater treatment plants are an integral part of a comprehensive wastewater treatment system in rural areas, where for economic reasons the construction of sewerage systems and collective sewage treatment plants is economically unjustified [1-6]. According to CSO data [7], there are currently around 217,000 household sewage treatment plants in Poland, among which the following systems are used: 1) a drainage pipe; 2) a sand filter; 3) a biological filter; 4) activated sludge; 5) constructed wetland, 6) hybrid system (activated sludge + biological filter) [5].

Among the aforementioned solutions, the most frequently used technological system consists of the initial settling tank and drainage pipe [8-10], mainly due to the low construction costs [11]. However, the application of this solution is the reason of much controversy in Poland $[6,12-14]$. The multi-criteria analysis shows that the usage of systems with drainage pipe is inconsistent with the principles of sustainable development [5], because these systems collecting polluted water and let in untreated sewage into the environment and not ensure effective elimination of pollution [15]. They have a negative impact on the ecological status of the environment and contribute to the degradation of groundwater quality [14].

The exploitation of small wastewater treatment plants is significantly different from the one recommended to large facilities. First of all, small sewage treatment plants are exposed to very large irregularities in the amount and composition of incoming sewage. Therefore, the wastewater treatment technology used in household wastewater treatment plants should be chosen in such a way to ensure an adequate ecological effect, combined with low maintenance requirements and minimum exploitation costs. According to Mucha and Mikosz [16], taking the basic principles of sustainable development into account, the paramount criterion in the selection of the technology for a small sewage treatment plant should be the ecological criterion which means the efficiency of wastewater treatment (Figure 1).

Other criteria include:

- environmental criteria (impact on the natural environment and aesthetics),

- technical criteria (ease of use and maintenance and modernity of the solution),

- reliability criterion (reliability of operation),

- economic criteria (investment and operational costs). 


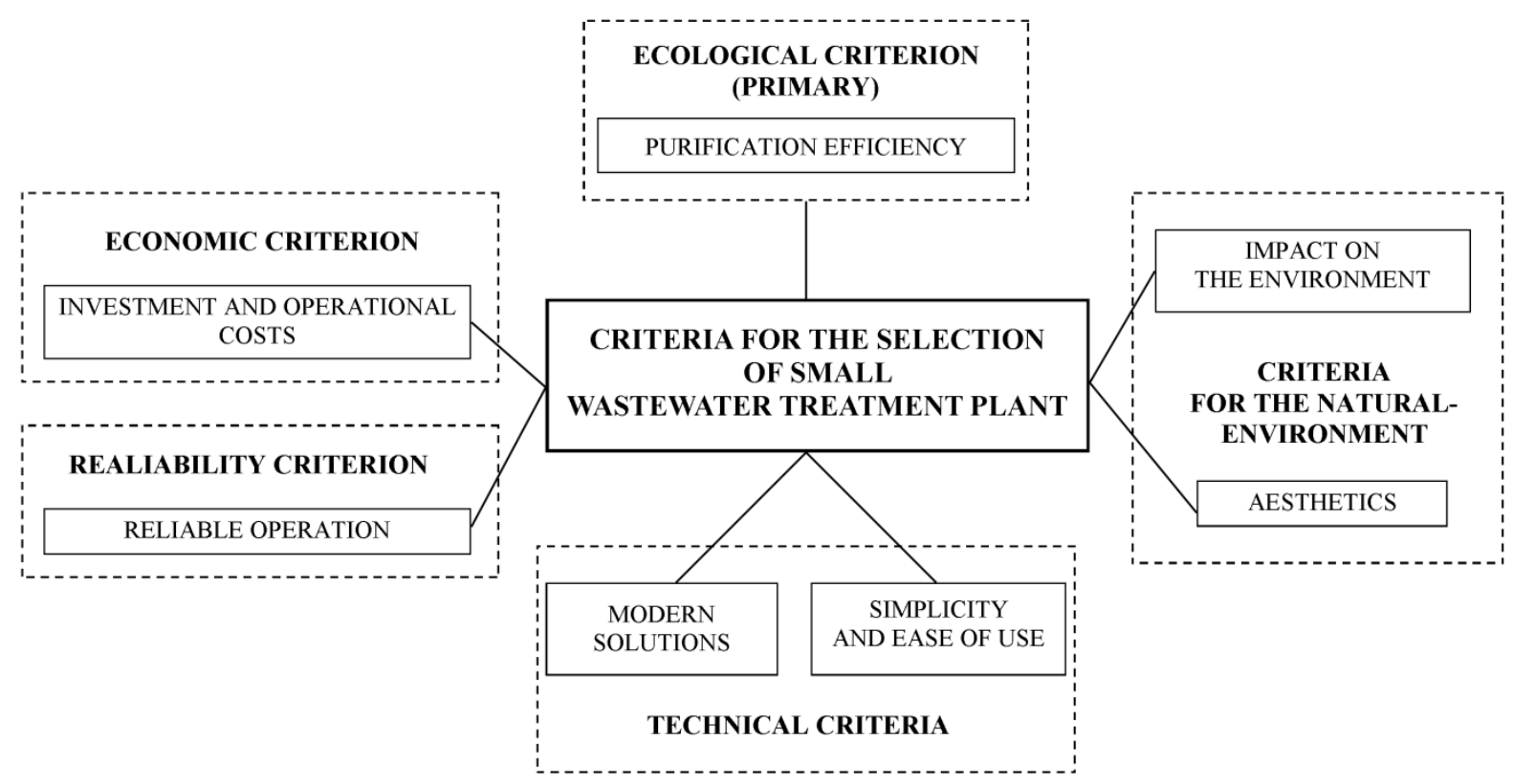

Fig. 1. Criteria of selection for small WWTPs according to sustainability principles [16]

In recent years, systems that meet most of the above-mentioned criteria are becoming more and more popular in Poland and around the world. These include technological systems with active sludge (mainly SBR - Sequential Biological Reactor), or with a biological bed (disc or sprayed), as well as hybrid systems- a combination of these two solutions [17-20]. Taking the ecological, and not only economical, aspect into consideration it is important that the technological system chosen by the user of a household sewage treatment plant should meet certain requirements included in legal regulations [21]. It should also be taken into account that there are many factors dependent and independent on the user, but affecting the efficiency of small wastewater treatment plants. One of the most important factors affecting the proper course of biological wastewater treatment processes is the temperature of air and sewage [22]. Therefore, in countries where climate conditions are characterized by significant variability of air temperature in different seasons, the used solutions should ensure high operational reliability and high effects of pollution removal in different seasons.

In recent years, for the treatment of small amounts of wastewater, more and more often constructed wetland systems (CWs) are used, which are easy to use and have an aesthetic appearance, and at the same time they ensure quite effective removal of pollutants. Jóźwiakowski et al. [15] proved that the usage of these systems is consistent with the principles of sustainable development. The literature suggests that CWs can purify various types of wastewater and are used in various climate conditions [23-25]. In Poland, such systems have been used in various technological configurations for about 30 years [26]. The research 
concerning CWs in recent years focus mainly on the processes and effects of pollution removal $[24,27-30]$, as well as determining the reliability of these systems [31-39] or the use of online systems to check the performance of the CW [40]. However, most of the existing papers usually describe the reliability of CWs at a given time, without taking into account changes in thermal conditions during the year. Therefore, the aim of this work is to determine the technological reliability of pollutions removal in one-stage constructed wetland system with horizontal flow in different seasons in the conditions of moderate climate.

\section{Material and methods}

\subsection{Characteristics of the experimental facility}

The analyzed treatment plant consists of an initial settling tank and a bed with a horizontal sewage flow with $1.2 \mathrm{~m}$ deep and with a surface area of $186 \mathrm{~m}^{2}$. The bed was planted by willow (Salix viminalis L.) (Photo 1). The willow species Salix viminalis L. began to be used in CWs in the 1990's [41-42]. It has been shown too, that such systems with willow can be used not only for wastewater treatment, but also for production of biomass for energy purposes [43].

The construction of the analyzed wastewater treatment plant has been described earlier in the papers of Jóźwiakowski et al. [37-38]. The tested facility is located in south-eastern Poland in Jastków $\left(51^{\circ} 18^{\prime} \mathrm{N}, 22^{\circ} 26^{\prime} \mathrm{E}\right)$. It is used to treat domestic wastewater coming from a building inhabited by 12 people, which has access to tap water, which is used to meet the basic needs of the residents (for bathing, washing-up, flushing the toilet and washing).

Considering the amount of inflow to the treatment plant, which during the experimental period was $\mathrm{Q}=1,2 \mathrm{~m}^{3} / \mathrm{d}$, the analyzed object, according to legal acts in Poland, is included in the group of so-called household wastewater treatment plants [6, 44-45].
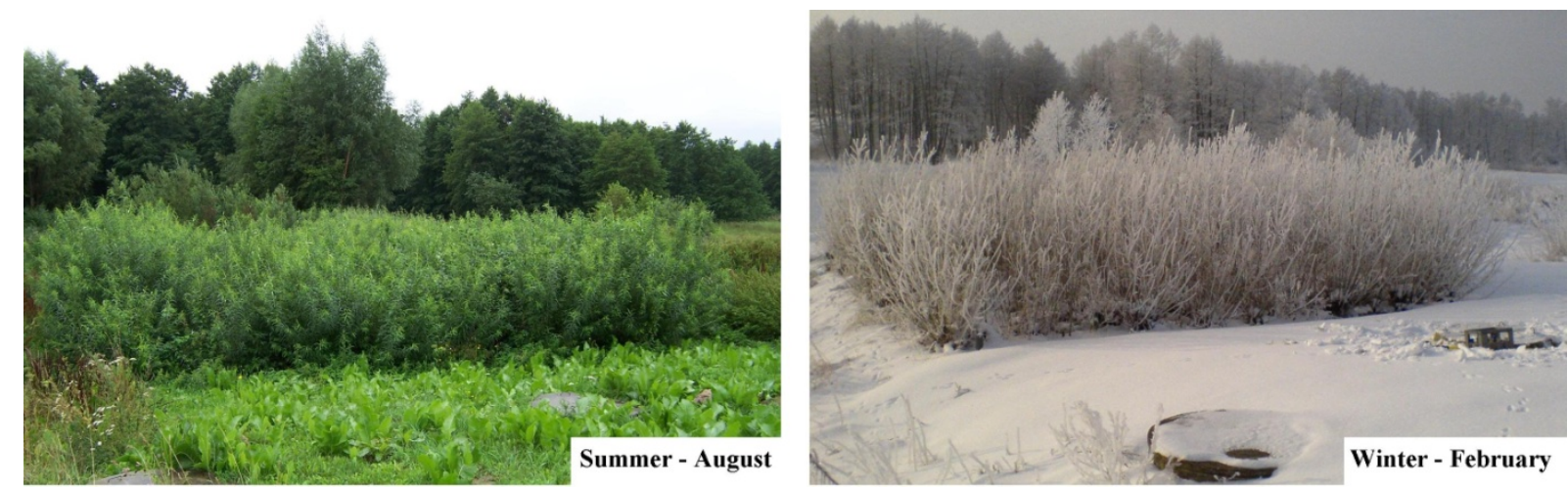

Photo. 1. One-stage constructed wetland in the summer and in the winter [46] 


\subsection{Climate conditions}

The region, where treatment plant is located, has a temperate climate with visible influences of the continental climate. The climate in this area is formed by polar air masses (PP) which dominate in the year, especially the polar-marine air (PPM), which constitutes $60-66 \%$ of air masses per year and occurs mainly in summer and polar-continental air (PPk), which accounts for $24-31 \%$ of air masses per year and occurs mainly in February and during spring and autumn. The polar-sea air flows from the west, bringing moisture from the Atlantic sea. In winter, it causes thaw and warming with snow or rain, and cooling, cloudiness, rainfall and frequent thunderstorms in summer. The polar-continental air flows from Asia and Eastern Europe and is characterized by low humidity, in winter it brings fall in temperature and cloudless sky, and during summer, sunny, hot and dry weather [47]. High variability of weather during the year causes occurrence of 4 basic seasons (winter, spring, summer, autumn) with variable air temperatures.

The research on the operation of the wastewater treatment plant was carried out for 14 years (1997-2010). Sewage samples from the sewage treatment plant for analysis were collected in 4 seasons (winter - February, spring - May, summer - August, autumn - November).

\subsection{Analytical methods}

Bearing in mind the 14-year research period in each season (winter, spring, summer and autumn), analysis of 14 samples of sewage inflowing and outflowing from the treatment plant was performed. In total, 56 series of analyses were carried out during the tests and 112 sewage samples were collected, in which the values of organic pollutants were determined using indicators such as $\mathrm{BOD}_{5}$ and $\mathrm{COD}$ as well as biogenic impurities: total nitrogen and total phosphorus.

$\mathrm{BOD}_{5}$ was measured by the dilution method using a WTW Oxi 538 portable meter - after Siwiec et al. [48]. COD was determined using a PC Spectro spectrophotometer manufactured by AQUALYTIC, after oxidation of the samples at $148^{\circ} \mathrm{C}$ in a WTW CR4200 thermo reactor. Total nitrogen was determined using a PC Spectro spectrophotometer manufactured by AQUALYTIC, after oxidation of the samples at $100^{\circ} \mathrm{C}$ in a WTW CR4200 thermo reactor. Total phosphorus was determined using a MPM 2010 spectrophotometer manufactured by WTW, after oxidation of the samples at $120^{\circ} \mathrm{C}$ in a WTW CR4200 thermo reactor. Sampling, sample transportation, processing and analysis have been done according to relative Polish Standards of Wastewater Examination which are compatible with APHA [49-50]. 
Acceptable (maximum) values for the 4 analyzed indicators, were adopted according to legal regulations binding in Poland [51]. According to these legal acts, the permissible values of pollutants in wastewater discharged from small wastewater treatment plants (from less than 2000 inhabitants) for the analyzed indicators are: $\mathrm{BOD}_{5}-40 \mathrm{mg} / \mathrm{l}$; COD $-150 \mathrm{mg} / \mathrm{l}$; total nitrogen $-30 \mathrm{mg} / \mathrm{l}$; total phosphorus $-5 \mathrm{mg} / \mathrm{l}$.

\subsection{Statistical methods}

On the basis of the obtained data, the technological reliability of the tested object was determined in various seasons during long-term operation. For this purpose, the Weibull method was used, which according to different authors $[36-38,52]$ is a useful general probability distribution that is still more often used to determine the technological operation reliability of wastewater treatment plants. The Weibull distribution can be used when the intensity of the exceedance of permissible values of pollution indicators is a variable with a monotonic course. The Weibull distribution is characterized by the probability density function (1) with the parameters b, c and $\theta$ :

$$
f(x)=\frac{c}{b} \cdot\left(\frac{x-\theta}{b}\right)^{(c-1)} \cdot e^{-\left(\frac{x-\theta}{b}\right)^{c}}
$$

Where:

$\mathrm{x}$ - variable defining the concentration of the pollutant index in treated wastewater,

b - scale parameter,

c - shape parameter,

$\theta$ - position parameter.

Assuming: $\theta<\mathrm{x}, \mathrm{b}>0, \mathrm{c}>0$

The Weibull distribution parameters were estimated using the method characterized by the highest likelihood. The quality of matching the Weibull distribution to empirical data was carried out with the Hollander-Proschan test. The analysis of this part of the study results was carried out using the STATISTICA 8 program. The calculated parameters of scale, shape and position for particular indicators in treated wastewater are presented in the table 3.

The interpretation of the variation coefficient $(\mathrm{Cv})$, in regard to the concentration of the analyzed indicators in sewage inflowing and outflowing from the treatment plant, was characterized according to the guidelines proposed by Mucha [53]. 


\section{Results}

\subsection{Thermal conditions in the research period}

In the discussed multi-year period (1997-2010), the median of temperature in individual months of the year, in the place where the treatment plant is located, ranged from $-2.2^{\circ} \mathrm{C}-$ in January to $19.2^{\circ} \mathrm{C}-$ in July (Figure 2).

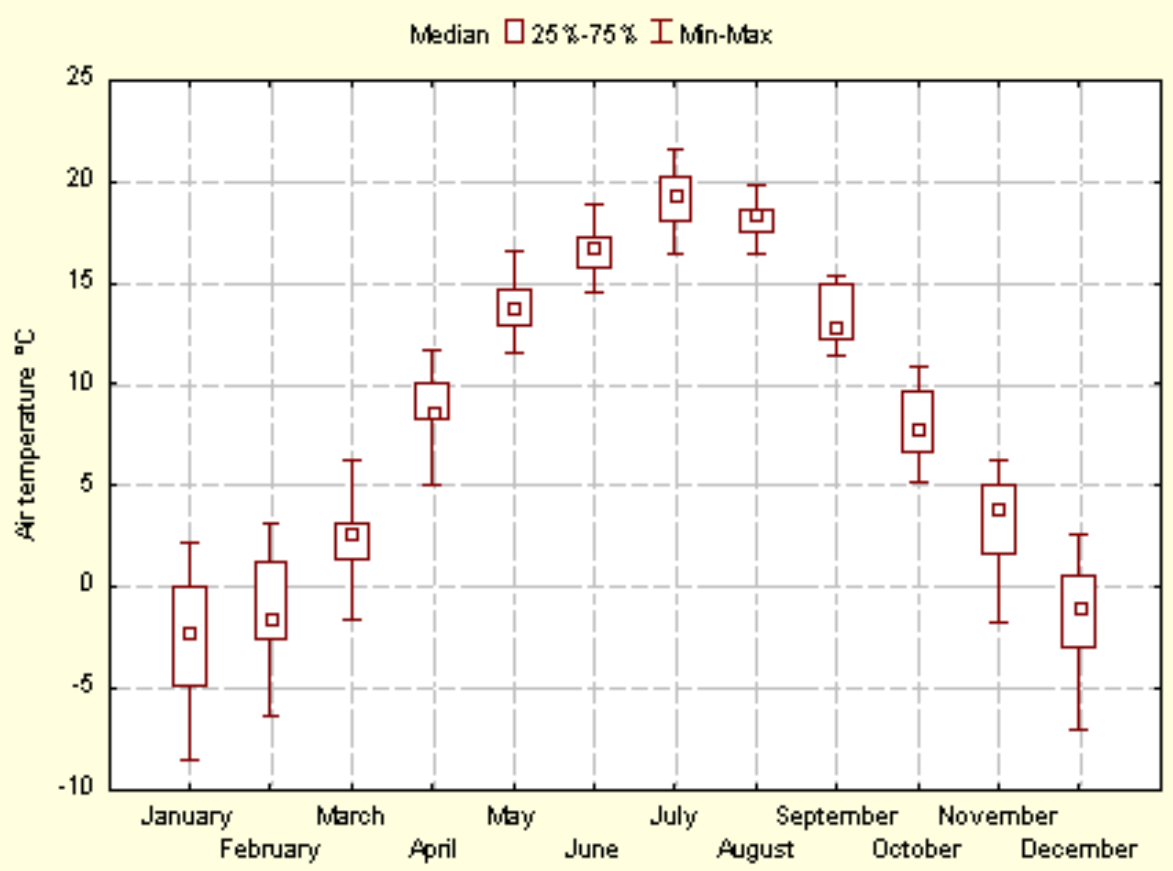

Fig. 2. Multi-year medians of atmospheric air temperature in different months of the discussed multi-year period 1997-2010 (based on the data from a meteorological station in Lublin $12 \mathrm{~km}$ away from the location of the experimental object [54])

The long-term medians of air temperature in particular seasons (winter, spring, summer, autumn) were: $-1.8 ; 13.8 ; 18.3$ and $3.5^{\circ} \mathrm{C}$, respectively. Therefore, the analysis of these data indicates that the most favorable thermal conditions for the course of basic pollution removal processes in the analyzed facilities prevailed in May and in August (when temperature was above $\left.5^{\circ} \mathrm{C}\right)$.

\subsection{Pollutant concentrations in inflowing wastewater}

The values of pollutants in wastewater flowing into the treatment plant were similar to those noted in other domestic sewage [55-57]. The median for $\mathrm{BOD}_{5}$ in the analyzed wastewater was $162.0 \mathrm{mg} / \mathrm{l}$, with an arithmetic mean of $170.5 \mathrm{mg} / \mathrm{l}$, while the median for COD was $339.0 \mathrm{mg} / \mathrm{l}$, with an arithmetic mean of $339.4 \mathrm{mg} / \mathrm{l}$. For biogenic indicators, i.e. total 
nitrogen and phosphorus, the overall median was 70.4 and $25.2 \mathrm{mg} / \mathrm{l}$, respectively, with an arithmetic mean of $71.5 \mathrm{mg} / 1$ for total nitrogen and $24.8 \mathrm{mg} / 1$ for total phosphorus (Tab. 1).

Table 1. Pollutant concentrations in inflow wastewater [37-38]

\begin{tabular}{ccccccc}
\hline & \multicolumn{6}{c}{ Statistics } \\
\cline { 2 - 7 } Index & $\begin{array}{c}\text { Average } \\
{[\mathrm{mg} / \mathrm{l}]}\end{array}$ & $\begin{array}{c}\text { Median } \\
{[\mathrm{mg} / \mathrm{l}]}\end{array}$ & $\begin{array}{c}\text { Min. } \\
{[\mathrm{mg} / \mathrm{l}]}\end{array}$ & $\begin{array}{c}\text { Max. } \\
{[\mathrm{mg} / \mathrm{l}]}\end{array}$ & $\begin{array}{c}\text { Standard } \\
\text { of deviation } \\
{[\mathrm{mg} / 1]}\end{array}$ & $\begin{array}{c}\text { Coefficient } \\
\text { of variation } \\
{[-]}\end{array}$ \\
\hline $\mathrm{BOD}_{5}$ & 170.5 & 162.0 & 62.0 & 441.0 & 69.7 & 0.41 \\
\hline $\mathrm{COD}$ & 339.4 & 339.0 & 101.0 & 700.0 & 116.2 & 0.34 \\
\hline $\begin{array}{c}\text { Total } \\
\text { nitrogen }\end{array}$ & 71.5 & 70.4 & 37.1 & 137.0 & 21.5 & 0.30 \\
\hline $\begin{array}{c}\text { Total } \\
\text { phosphorus }\end{array}$ & 24.8 & 25.2 & 5.2 & 42.8 & 8.8 & 0.36 \\
\hline
\end{tabular}

In the case of the analyzed organic and biogenic indicators, the average variation in their value in sewage flowing into the treatment plant was found, which was indicated by the calculated coefficients of variation. The lowest variation of values was stated for total nitrogen, whose coefficient of variation was $\mathrm{W}_{\mathrm{z}}=0.30$, while the highest variation of results was observed for $\mathrm{BOD}_{5}-$ the coefficient of variation was $\mathrm{W}_{\mathrm{z}}=0.41$. Therefore, it can be concluded that in the analyzed treatment plant with a generally constant amount of incoming sewage, a permanent level of charges of organic and biogenic contaminants was noted, which should not affect the instability of the transformation processes of organic and biogenic compounds in the bed. Moreover, it was found that the seasons of year didn't impact for the concentrations of particular of organic and biogenic indicators in raw wastewater.

\subsection{Pollutant concentrations in outflowing wastewater}

Table 2 and Figures 3 and 4 present characteristic values of organic and biogenic contaminants in sewage flowing out of the wastewater treatment plant in particular seasons.

Table 2. Pollutant concentrations in outflowing wastewater in different seasons

\begin{tabular}{cccccccc}
\hline \multirow{3}{*}{ Index } & Period & \multicolumn{6}{c}{ Statistics } \\
\cline { 3 - 8 } & $\begin{array}{c}\text { Average } \\
{[\mathrm{mg} / \mathrm{l}]}\end{array}$ & $\begin{array}{c}\text { Median } \\
{[\mathrm{mg} / \mathrm{l}]}\end{array}$ & $\begin{array}{c}\text { Min. } \\
{[\mathrm{mg} / \mathrm{l}]}\end{array}$ & $\begin{array}{c}\text { Max. } \\
{[\mathrm{mg} / \mathrm{l}]}\end{array}$ & $\begin{array}{c}\text { Standard } \\
\text { of deviation } \\
{[\mathrm{mg} / \mathrm{l}]}\end{array}$ & $\begin{array}{c}\text { Coefficient } \\
\text { of variation } \\
{[-]}\end{array}$ \\
\hline \multirow{3}{*}{ BOD $_{5}$} & winter & 23.1 & 23.1 & 7.1 & 56.0 & 13.1 & 0.57 \\
\cline { 2 - 8 } & spring & 31.8 & 22.5 & 10.7 & 105.8 & 25.0 & 0.79 \\
\cline { 2 - 8 } & summer & 22.0 & 23.1 & 7.0 & 36.1 & 8.7 & 0.39 \\
\hline
\end{tabular}




\begin{tabular}{cccccccc}
\hline & autumn & 16.1 & 10.8 & 6.1 & 52.4 & 12.6 & 0.78 \\
\hline \multirow{4}{*}{ COD } & winter & 54.3 & 52.5 & 20.0 & 99.0 & 20.7 & 0.38 \\
\cline { 2 - 7 } & spring & 73.7 & 52.5 & 39.0 & 210.0 & 45.4 & 0.62 \\
\cline { 2 - 7 } & summer & 58.9 & 48.5 & 15.0 & 134.0 & 36.4 & 0.62 \\
\cline { 2 - 7 } & autumn & 48.8 & 39.0 & 9.0 & 105.0 & 32.5 & 0.67 \\
\hline \multirow{3}{*}{$\begin{array}{c}\text { Total } \\
\text { nitrogen }\end{array}$} & winter & 34.2 & 35.5 & 10.9 & 48.5 & 8.9 & 0.26 \\
\cline { 2 - 7 } & spring & 36.6 & 34.8 & 17.8 & 56.7 & 10.5 & 0.29 \\
\cline { 2 - 7 } & summer & 35.2 & 30.5 & 17.0 & 92.0 & 18.6 & 0.53 \\
\cline { 2 - 7 } Total & autumn & 25.7 & 28.0 & 9.0 & 39.0 & 9.4 & 0.36 \\
\hline \multirow{3}{*}{\begin{tabular}{c} 
phosphorus \\
\cline { 2 - 7 }
\end{tabular}} & winter & 5.5 & 6.3 & 0.5 & 9.0 & 2.8 & 0.50 \\
\cline { 2 - 7 } & spring & 8.3 & 7.9 & 1.0 & 17.9 & 4.3 & 0.42 \\
\cline { 2 - 7 } & summer & 6.2 & 7.7 & 0.9 & 11.0 & 3.8 & 0.62 \\
\cline { 2 - 7 } & autumn & 4.3 & 4.5 & 0.1 & 10.0 & 2.8 & 0.66 \\
\hline
\end{tabular}
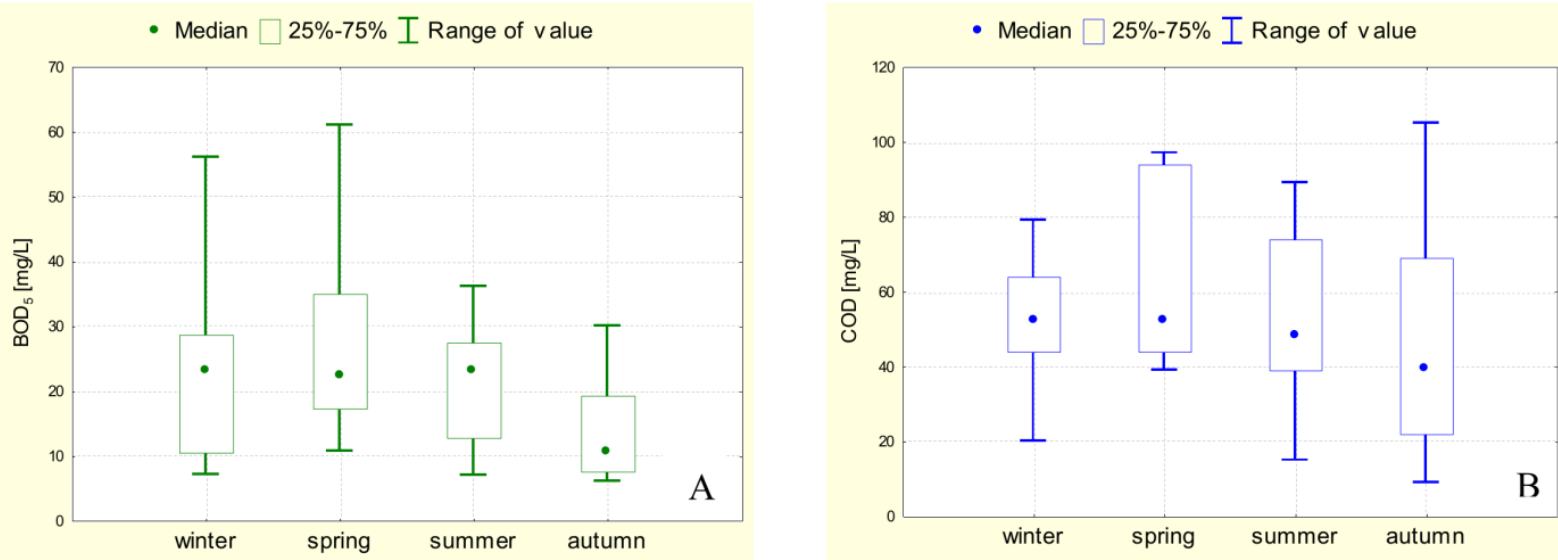

Fig. 3. Characteristic values of $\mathrm{BOD}_{5}(\mathrm{~A})$ and $\mathrm{COD}(\mathrm{B})$ in treated wastewater in particular seasons
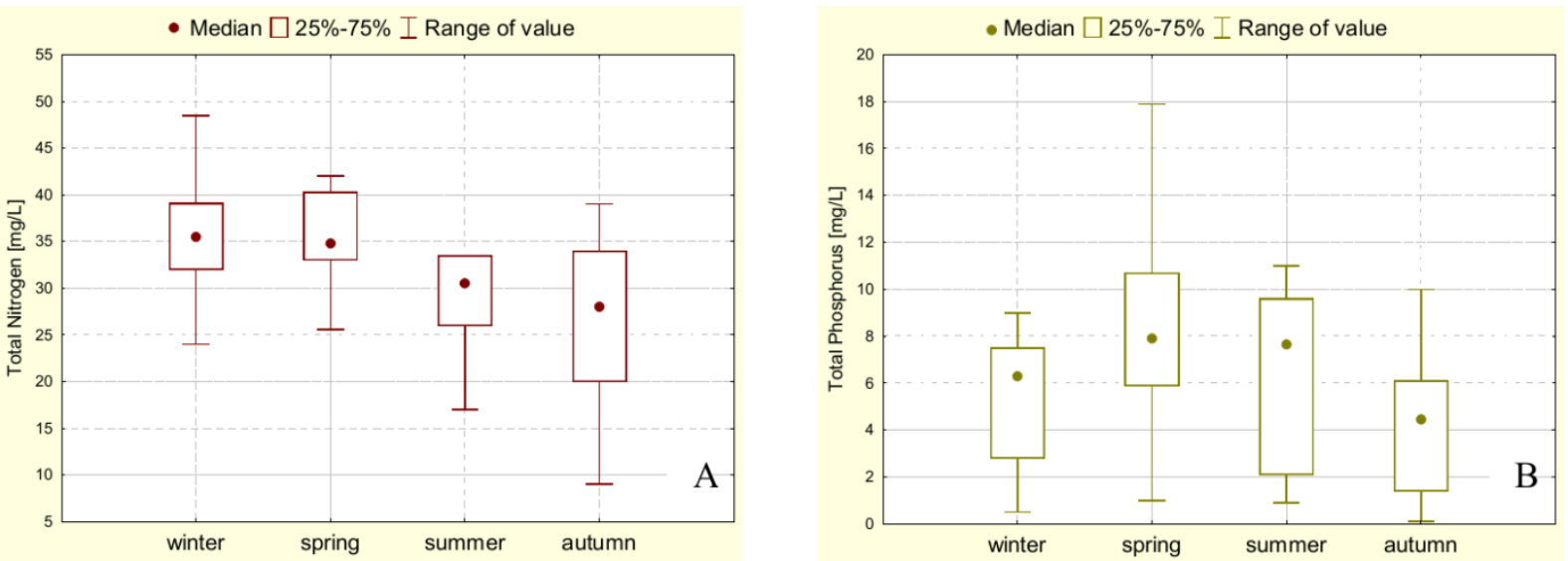

Fig. 4. Characteristic values of total nitrogen (A) and total phosphorus (B) in treated wastewater in particular seasons 
By analyzing the obtained results in detail, it was found that in the case of $\mathrm{BOD}_{5}$ in the seasons such as winter, spring and summer, the median of this parameter oscillated in the range from 22.5 to $23.1 \mathrm{mg} / \mathrm{l}$, while in autumn it was much lower and amounted to $10.8 \mathrm{mg} / \mathrm{l}$ (Fig. $3 \mathrm{~A})$. A similar relationship was observed in the case of COD, since the median from winter to summer ranged from 48.5 to $52.5 \mathrm{mg} / \mathrm{l}$, while in autumn it was lower and was $39.0 \mathrm{mg} / \mathrm{l}$ (Fig. 3B).

By analyzing the concentrations of biogenic indicators, it was found that the median of total nitrogen and total phosphorus was the lowest in autumn. For total nitrogen, the median in autumn was $28.0 \mathrm{mg} / \mathrm{l}$, while for the remaining 3 seasons the median value ranged from 30.5 to $35.5 \mathrm{mg} / \mathrm{l}$ (Figure 4A). For the second biogenic indicator, which is total phosphorus, the overall median during autumn was the lowest and amounted to $4.5 \mathrm{mg} / \mathrm{l}$, while for other periods the median for total phosphorus varied from 6.3 to $7.9 \mathrm{mg} / \mathrm{l}$ (Fig. 4B).

Figures 3 and 4 show the median, quartile range $25 \%-75 \%$, which specifies the length of the part of the variability range of particular indicators, in which there are $50 \%$ of the "middle" values and the range of irrelevant values for the indicators. The variability expressed by the coefficient of variation $\mathrm{W}_{\mathrm{z}}$ for the analyzed parameters in treated wastewater was on a variable level during particular seasons of the year. For $\mathrm{BOD}_{5}$ the coefficient of variation in summer was $\mathrm{W}_{\mathrm{z}}=0.39$ and can be defined as the average diversity. In contrast, in winter it was $\mathrm{W}_{\mathrm{z}}=$ 0.57, which indicates large variety. In the other two seasons, i.e. in spring and autumn, the $\mathrm{BOD}_{5}$ values in treated wastewater were very diverse, as indicated by unevenness coefficients of $\mathrm{W}_{\mathrm{z}}=0.79$ and 0.78 , respectively.

The average variation of COD values was observed only during winter, because the coefficient of variation was $\mathrm{W}_{\mathrm{z}}=0.38$. In the remaining three seasons, the COD values in treated wastewater were very diverse, since the coefficient of variability of $\mathrm{W}_{\mathrm{z}}$ varied from 0.62 to 0.67 . However, in the case of biogenic indicators, the average variation of total nitrogen concentration was observed in the following seasons: winter, spring and autumn, when the coefficient of variation of $\mathrm{W}_{\mathrm{z}}$ varied from 0.26 to 0.36 . In contrast, in summer the variability of the concentration of this parameter was very different and amounted to $\mathrm{W}_{\mathrm{z}}=0.53$. The concentration of total phosphorus in all study periods showed a high level of variation in treated wastewater, as indicated by variation coefficients oscillating from $\mathrm{W}_{\mathrm{z}}=0.50$ to 0.66 .

Summing up the obtained results, it can be concluded that the processes of impurities removal in the CWs was unstable in different seasons, which is indicated by large or very large differences in the concentration of the analyzed organic and biogenic indicators in sewage flowing out of this bed. 


\subsection{The reliability of pollutions removal in different seasons}

The main aim of this work is to determine reliability indices for the removal of organic and biogenic pollutants in individual seasons, using Weibull's reliability theory. For estimated distribution parameters, the hypothesis of accepting Weibull distribution for the approximation of empirical data was verified. As a result of the statistical analysis carried out concerning the test probability $\mathrm{p}$, it was found that empirical data could be described by the Weibull distribution and taken as a zero hypothesis. The results of the distribution alignment with HollanderProschan test and the estimated scale, shape and position parameters are presented in Table 3.

Table 3. Results of the estimation of the Weibull distribution parameters together with the measures of goodness of fit to empirical data

\begin{tabular}{llllccc}
\hline \multirow{2}{*}{ Index } & \multirow{2}{*}{ Period } & \multicolumn{3}{c}{ Distribution parameters } & \multicolumn{2}{c}{ Test Hollandera-Proschana } \\
\cline { 2 - 7 } & & $\mathrm{b}$ & $\mathrm{c}$ & $\theta$ & Test value & $\mathrm{p}$ \\
\hline \multirow{3}{*}{ BOD $_{5}$} & winter & 26.147 & 1.9408 & 5.1818 & 0.071593 & 0.94293 \\
\cline { 2 - 7 } & spring & 35.693 & 1.5123 & 9.5960 & 0.326170 & 0.74430 \\
\cline { 2 - 7 } & summer & 24.754 & 2.9608 & -1.0000 & -0.123561 & 0.90166 \\
\cline { 2 - 7 } & autumn & 18.074 & 1.5023 & 5.9495 & 0.297780 & 0.76969 \\
\hline \multirow{4}{*}{ COD } & winter & 60.884 & 2.9205 & 0.1818 & 0.118291 & 0.90584 \\
\cline { 2 - 7 } & spring & 83.712 & 1.8490 & 0.3869 & 0.293177 & 0.76939 \\
\cline { 2 - 7 } $\begin{array}{l}\text { Total } \\
\text { nitrogen }\end{array}$ & summer & 66.625 & 1.8028 & 8.9091 & 0.223934 & 0.82281 \\
\cline { 2 - 7 } & autumn & 54.627 & 1.6069 & 5.5556 & 0.085200 & 0.93210 \\
\hline \multirow{3}{*}{$\begin{array}{l}\text { Total } \\
\text { phosphorus }\end{array}$} & winter & 37.227 & 4.9164 & -2.0000 & -0.297564 & 0.76604 \\
\cline { 2 - 7 } & spring & 40.360 & 3.8381 & 4.2626 & 0.198595 & 0.84258 \\
\cline { 2 - 7 } & summer & 33.756 & 3.6672 & 11.7370 & 0.257319 & 0.79683 \\
\hline & autumn & 28.732 & 3.3025 & -1.0000 & -0.206697 & 0.83625 \\
\hline & winter & 6.1705 & 2.0767 & -1.0000 & -0.406984 & 0.68402 \\
\cline { 2 - 7 } & spring & 9.3381 & 2.0261 & -2.0000 & -0.232317 & 0.81676 \\
\cline { 2 - 7 } & summer & 6.8573 & 1.6109 & 0.6778 & -0.201559 & 0.84026 \\
\cline { 2 - 7 } & autumn & 4.5657 & 1.3091 & 0.0000 & -0.402418 & 0.68738 \\
\hline
\end{tabular}

In the case of $\mathrm{BOD}_{5}$, taking into account the occurrence of the maximum value, i. e. the limit value for this parameter of $40 \mathrm{mg} / 1$, the calculated technological reliability for different seasons are: in winter - 90\%, in spring - 70\%, in summer - 100\% and autumn - 97\% (Fig. 5). On the basis of the data obtained, it can be concluded that there is a volatility of organic pollutant removal processes in particular seasons, which affects the variability of reliability index values and at the same time the effectiveness of reducing $\mathrm{BOD}_{5}$ in the constructed wetland during the year. Bearing in mind that in each of the 4 seasons the number of days is about 90 , it can be concluded that in winter the limit for $\mathrm{BOD}_{5}$ can be exceeded in 9 days and in spring 
305

in 27 days. In summer the limit value for $\mathrm{BOD}_{5}$ was not exceeded, whereas in autumn the limit value for this parameter may be exceeded in about 3 days. Therefore, in the case of $\mathrm{BOD}_{5}$, the highest probability of occurrence of a value higher than the acceptable value is in spring (Fig. $5 B)$, i. e. at a time when the vegetation period is just beginning in the region where the examined treatment plant is located. In summer and autumn, during the period of plant vegetation inhibition, the reliability of organic matter removal expressed by $\mathrm{BOD}_{5}$ in the constructed wetland is at a very high level, and the risk of occurrence of a value higher than the acceptable value for this parameter is negligible (Fig. 5C, Fig. 5D).
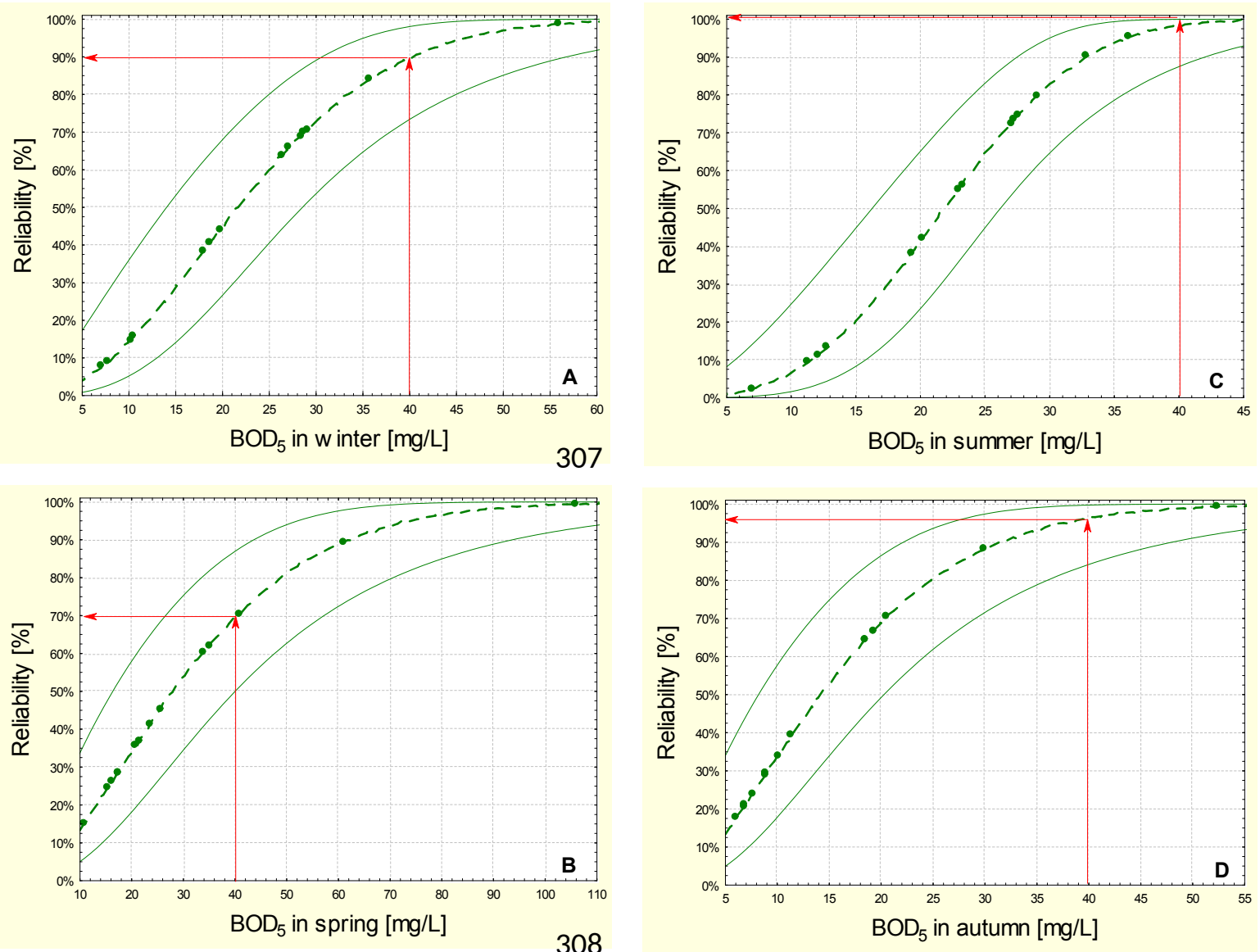

Fig. 5. Technological reliability for $\mathrm{BOD}_{5}$ decrease in the wastewater treatment plant in different seasons (A - winter, B - spring, C - summer, D - autumn).

For COD, taking into account the occurrence of the maximum value, i. e. the limit value for this parameter of $150 \mathrm{mg} / \mathrm{l}$, the calculated technological reliability index in spring was $94 \%$ (Fig. 6B). Therefore, it can be concluded that in this 90-day period it is possible to exceed the limit value specified for COD in about 7 days. In the remaining 3 seasons (summer, autumn, winter) the technological reliability indexes of the technological occurrence of the limit value specified for COD were 100\% (Fig. 6A, Fig. 6C and Fig. 6D). It can therefore be concluded 
that the reliability indexes of COD decrease described by the Weibull model are at the highest level almost throughout the year. Only at the beginning of plant vegetation (spring), the reliability of the decrease in COD is at a lower level and during this period there is a likelihood that higher values of this parameter than the acceptable value will appear.
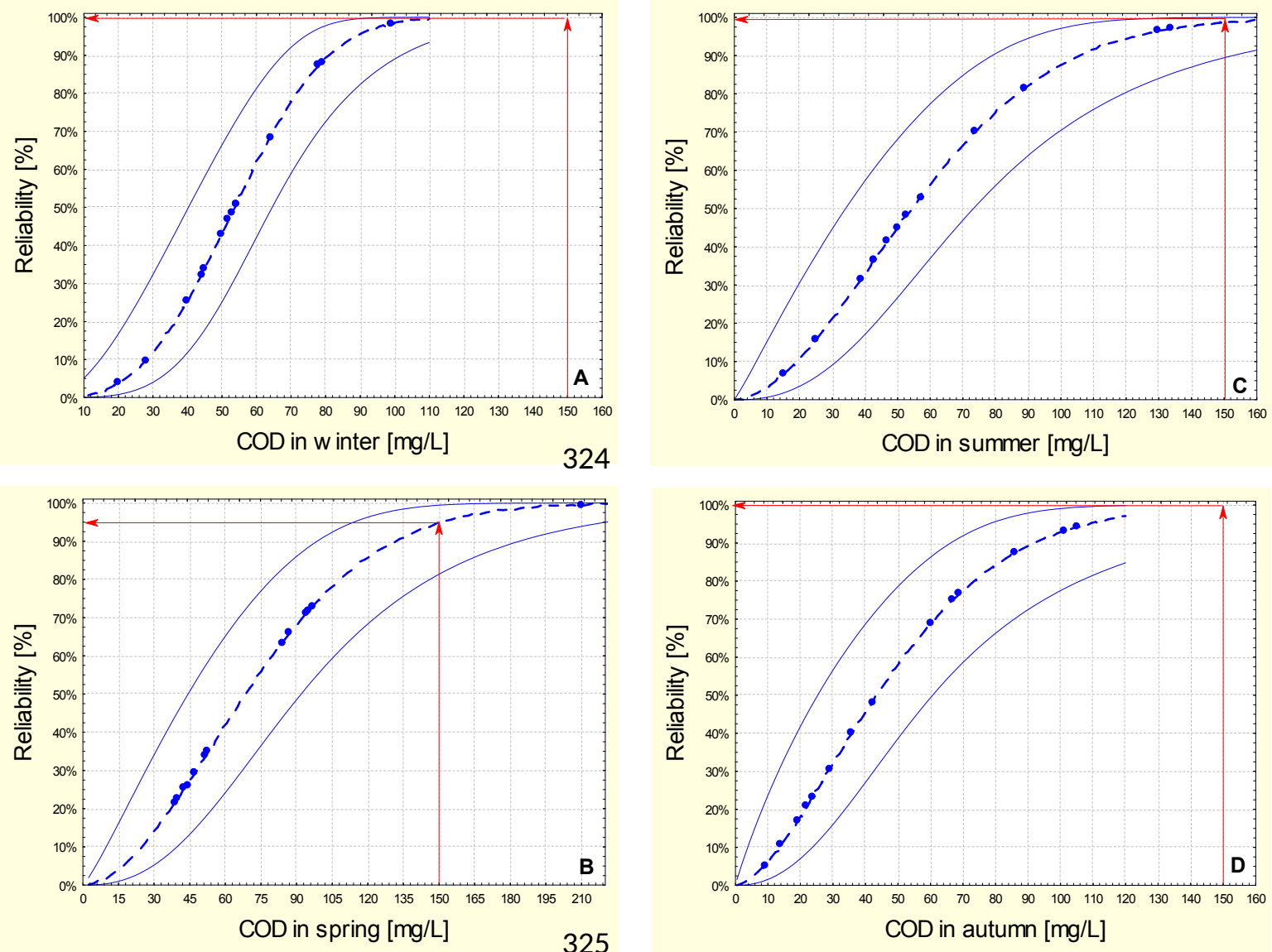

Fig. 6. Technological reliability for COD decrease in the wastewater treatment plant in different seasons (A - winter, B - spring, C - summer, D - autumn).

For total nitrogen, taking into account the occurrence of the maximum value, i. e. the limit value for this parameter of $30 \mathrm{mg} / 1$, the calculated technological reliability indexes for different seasons are: in winter $-30 \%$, in spring $-28 \%$, in summer - $48 \%$ and in autumn - $68 \%$ (Fig. 7 ). It can therefore be concluded that in the wastewater treatment plant analysed in winter and spring, the absorption and conversion of nitrogen compounds do not occur at a sufficient intensity, which results in the fact that the concentrations of this parameter in treated wastewater are often higher than the limit value. A higher concentration of total nitrogen than the limit value was found in 11 out of 14 samples during the winter. The concentrations of total nitrogen during this period ranged from 2 to $8.5 \mathrm{mg} / 1$ above the limit value (Fig. 7A). In spring, 11 out of 14 samples were also found to have a higher concentration of total nitrogen than the limit 
344

value. These overruns ranged from 3 to $16.7 \mathrm{mg} / 1$ above the limit value (Fig. 7B). Conversely, in summer 7 out of 14 samples taken were found to have a higher concentration of total nitrogen than the limit value and exceedances ranged from 1 to $21 \mathrm{mg} / \mathrm{l}$ (Fig. 7C). In autumn however, 5 cases of exceeding the limit value for total nitrogen in waste water treated with 14 analyses were found. These overruns ranged from 1.4 to $9.0 \mathrm{mg} / 1$ above the limit value (Fig. 7D).
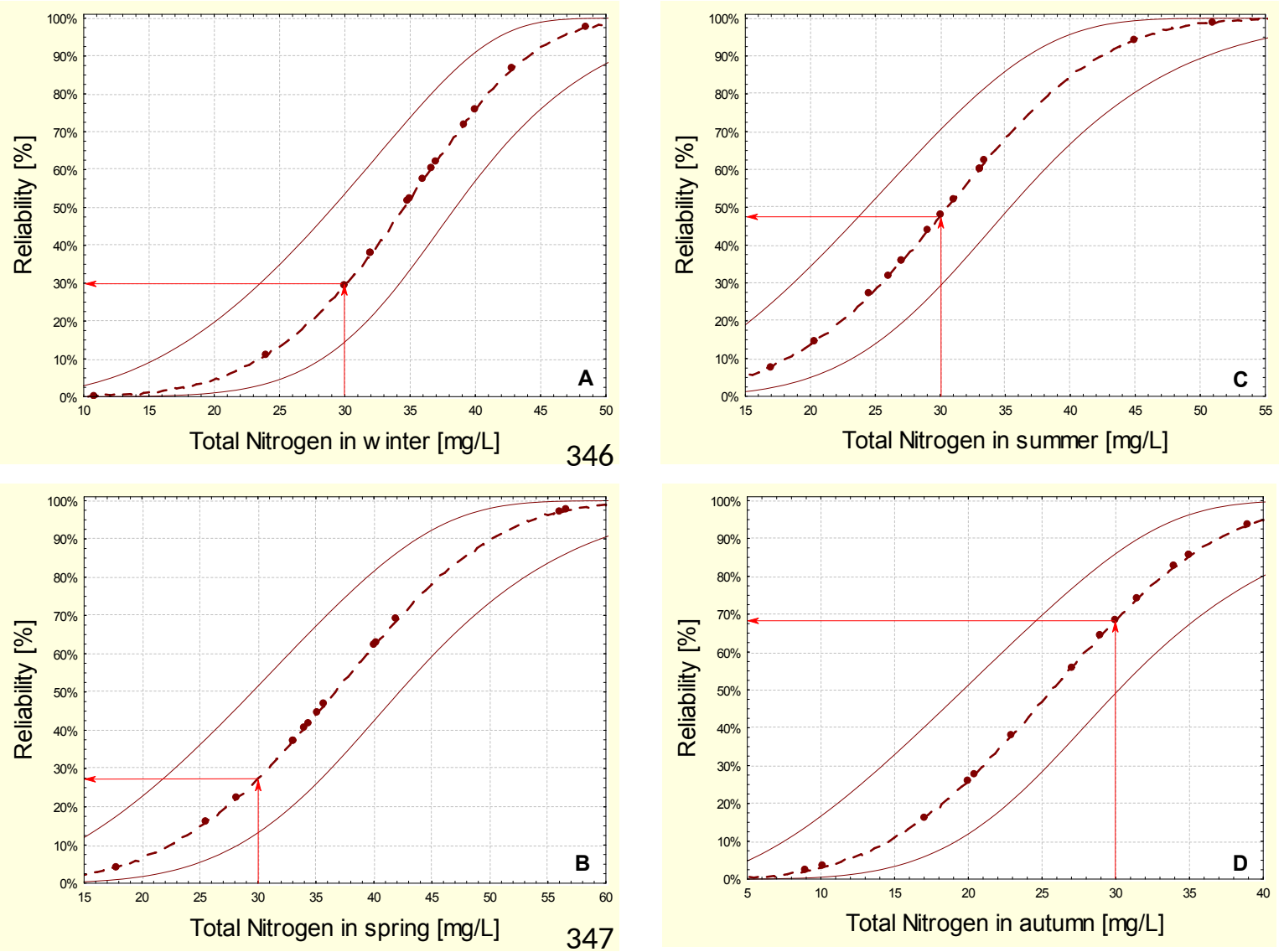

Fig. 7. Technological reliability for total nitrogen removal in the wastewater treatment plant in different seasons (A - winter, B - spring, C - summer, D - autumn).

The second of the analysed nutrient indices, i. e. total phosphorus, as in the case of the previous analysed parameters was unevenly removed in 4 analysed seasons of the year. For total phosphorus, taking into account the occurrence of the maximum value, i. e. the limit value for this parameter of $5 \mathrm{mg} / \mathrm{l}$, the calculated technological reliability indexes for the different seasons are: in winter - $48 \%$, in spring - 23\%, in summer - $45 \%$ and in autumn - $68 \%$ (Fig. 8 ). In the winter period, 9 out of 14 samples taken were found to have a higher concentration of total phosphorus than the limit value. Total phosphorus concentrations during this period ranged from 0.7 to $4.0 \mathrm{mg} / \mathrm{l}$ above the limit value (Fig. 8A). In the spring, 12 out of 14 samples taken were found to have a higher concentration of total phosphorus than the limit value. These 
excesses ranged from 0.3 to $12.9 \mathrm{mg} / \mathrm{l}$ above the limit value (Fig. 8B). In summer, in 8 out of 14 samples, the total phosphorus concentration was higher than the limit value and the exceedances ranged from 1.8 to $6.0 \mathrm{mg} / \mathrm{l}$ (Fig. 8C). However, in autumn 6 cases of exceeding the limit value for total nitrogen in waste water treated with 14 analyses were found. These excesses ranged from 0.6 to $5.0 \mathrm{mg} / \mathrm{l}$ above the limit value (Fig. 8D).
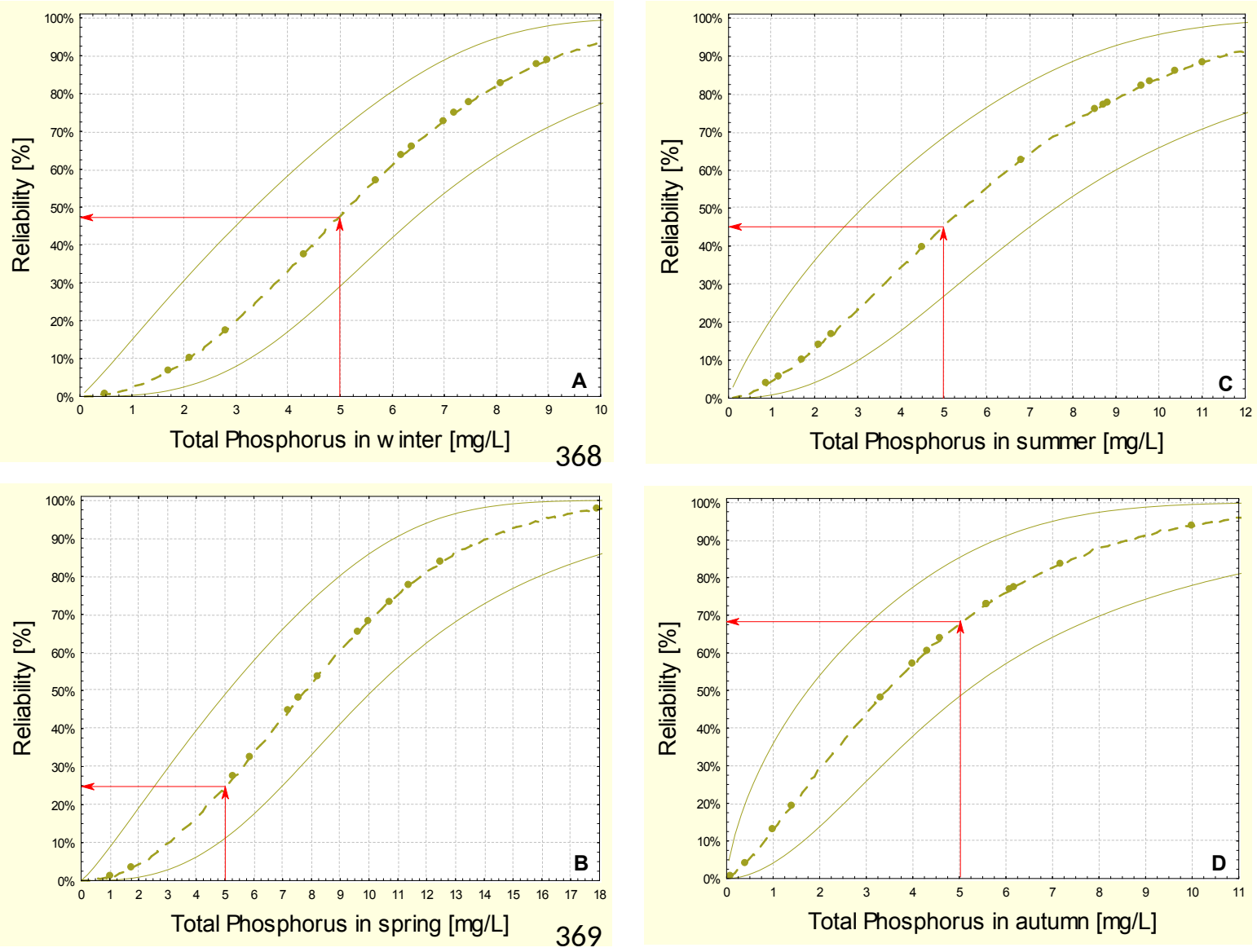

Fig. 8. Technological reliability for the total phosphorus removal in the wastewater treatment plant in different seasons (A - winter, B - spring, C - summer, D - autumn).

\section{Discussion}

Research shows that the technological reliability of the operation of a single-stage horizontal water treatment plant is unsatisfactory with respect to the removal of nutrient pollutants, i. e. total nitrogen and total phosphorus. On the other hand, the reliability of organic pollutant removal only met the expected requirements in the case of COD, whereas in the case of $\mathrm{BOD}_{5}$ a seasonal decrease of its reliability was observed. The lowest reliability indexes of the removal of pollutants were usually obtained in winter and spring, which may prove the influence of low air temperatures on the efficiency of wastewater treatment and reliability of operation of a single-stage constructed wetland wastewater treatment plant. According to Gajewska and Obarska-Pempkowiak [58] the effectiveness of constructed wetland systems 
with vertical flow in the climatic conditions of Poland is about $40 \%$ less effective in the period outside vegetation than in the growing season. Therefore, the results and literature data obtained indicate that single-stage constructed wetland systems do not provide stable and reliable removal of contaminants in different seasons during many years of operation. Therefore, they should not be recommended for wider use in temperate climate conditions. According to literature, hybrid constructed wetland systems provide much greater reliability in the removal of organic and biogenic contaminants under Polish conditions [36, 39]. The research of Jucherski et al. [36] show that in the modified hybrid system, in which a filter with LECA® was used in front of the constructed wetland bed, the reliability of reducing $\mathrm{BOD}_{5}$ and $\mathrm{COD}$ was about $100 \%$, while the reliability of removing total nitrogen and $\mathrm{PO}_{4}-\mathrm{P}$ was respectively 77 and $97 \%$.

In order to optimize phosphorus removal reliability in constructed wetland systems, the possibility of using special P-filters filled with carbonate-silica is recommended [59-60]. However, the reliability of nitrogen removal can be increased by using a non-conventional method of wastewater oxygenation using hydrogen peroxide [61].

\section{Conclusions}

The technological reliability of the analysed one-stage, horizontal flow constructed wetland wastewater treatment plant during 14 years of operation were variable in particular seasons of the year. The lowest reliability indexes of the removal of pollutants were usually obtained in winter and spring, which may prove the influence of low air temperatures on the efficiency of wastewater treatment and reliability of operation of a single-stage constructed wetland wastewater treatment plant. The results show that one-stage constructed wetland systems do not provide stable and reliable removal of contaminants in different seasons during many years of operation. Therefore, they should not be recommended for wider use in temperate climate conditions. In order to increase the technological reliability of this type of treatment plant, it is proposed to expand it by creating hybrid systems consisting of two beds with vertical and horizontal flow and a special P-filter.

\section{Acknowledgements}

This paper was written on the basis of the following research projects funded by the Scientific Research Committee and the Polish Ministry of Science and Higher Education of Poland:

- Operation of small wastewater treatment plants (contract no. TKD/BW/6, 1996-99),

- Shaping of water resources and wastewater treatment (contract no. TKD/BW/2, 2006-11), 
- Wastewater treatment and rural areas infrastructure (contract no. TKD/DS/1, 2012-15),

- Water, wastewater and energy management" (contract no. TKD/DS/1, 2016-17),

- Analysis of the effectiveness of domestic sewage treatment in the constructed wetlands (contract no. 5 P06H 02715, 1998-2000),

- Analysis of the functioning of small wastewater treatment plants in rural areas and attempts to increase their effectiveness in the aspect of environmental protection

(contract no. 3 P06S 058 23, 2002-04),

- Optimization of pollution removal processes in small wastewater treatment plants under model and field conditions (contract no. N N523 3495 33, 2007-10).

\section{References}

[1] D. Steer, L. Fraser, J. Boddy, B. Seibert, Efficiency of small constructed wetlands for subsurface treatment of single-family domestic effluent. Ecol. Eng. 18 (4) (2002) 429-440.

[2] H. Brix, C.A. Arias, The use of vertical flow constructed wetlands for on-site treatment of domestic wastewater: New Danish guidelines. Ecol. Eng. 25 (5) (2005) 491-500.

[3] D.C. Seo, R.D. DeLaune, W.Y. Park, J.S. Lim, J.Y. Seo, do J. Lee, J.S. Cho, J.S. Heo, Evaluation of a hybrid constructed wetland for treating domestic sewage from individual housing units surrounding agricultural villages in South Korea. J Environ Monit. 11 (1) (2009) 134-144.

[4] J. Mikosz, Wastewater management in small communities in Poland, Desalin. Water Treat. 51 (10-12) (2013) 2461-2466.

[5] K. Jóźwiakowski, Z. Mucha, A. Generowicz, S. Baran, J. Bielińska, W. Wójcik, The use of multi-criteria analysis for selection of technology for a household WWTP compatible with sustainable development. Archiv. Environ. Protec. 41 (3) (2015) 76-82.

[6] J. Pawełek, P. Bugajski, The development of household wastewater treatment plants in Poland - advantages and disadvantages. Acta Sci. Pol., Formatio Circumiectus, 16 (2) (2017) 3- 14 (in Polish).

[7] CSO - Central Statistical Office, Statistical Yearbook of the Republic of Poland (2017) Warszawa (in Polish).

[8] J. Pawełek, Degree of development and functionality of the water supply and sewage systems in rural Poland. Barometr Regionalny 14 (1) (2016) 141-149.

[9] K. Jóźwiakowski, D. Podbrożna, K. Kopczacka, M. Marzec, A. Listosz, P. Pochwatka, A. Kowalczyk-Juśko, A. Malik, The state of water and wastewater management in the municipalities of the Polesie National Park. J. Ecol. Eng. 18 (6) (2017) 192-199.

[10] A. Micek, M. Marzec, K. Jóźwiakowska, P. Pochwatka, The condition of sanitary infrastructure in the Parczew district and the need for its development. J. Ecol. Eng. 19 (6) (2018) 107-115.

[11] B. Karolinczak, R. Miłaszewski, A. Sztuk, Cost-effectiveness analysis of different technological variants of single-house sewage treatment plants. Rocz. Ochr. Środ. 17 (2015) 726-746 (in Polish).

[12] A. Jucherski, A. Walczowski, Drainage pipes. Treatment or discharging untreated sewage to the soil? Wiad. Melior. Łakk. 3 (390) (2001) 131-132 (in Polish). 
[13] J. Paluch, K. Pulikowski, Selected problems related to the construction of domestic sewage treatment plants with drainage pipe.. Wiad. Mel. i Łąk. 4 (2004) 191-198 (in Polish).

[14] K. Jóźwiakowski, A. Steszuk, A. Pieńko, M. Marzec, A. Pytka, M. Gizińska, B. Sosnowska, J. Ozonek, Evaluation of the impact of wastewater treatment plants with drainage system on the quality of groundwater in dug and deep wells. Inżynieria Ekologiczna 39 (2014) 74-84 (in Polish).

[15] T. Orlik, K. Jóźwiakowski, The evaluation of two BATEX household wastewater treatment plants with filter drain, Inżynieria Rolnicza 3 (45) (2003) 109-119 (in Polish).

[16] Z. Mucha, J. Mikosz, Rational application of small wastewater treatment plants according to sustainability criteria, Czasopismo Techniczne. Środowisko 106 (2) (2009) 91-100 (in Polish).

[17] P. R. Nagwekar, Removal of organic matter from wastewater by activated sludge process - review. International Journal of Science, Engineering and Technology Research 3 (5) (2014) 1260-1263.

[18] M. Marzec, Efficiency of removing organic pollutants from wastewater in a household wastewater treatment plant with a hybrid reactor. J. Ecol. Eng. 201617 (5) (2016) 240246.

[19] M. Marzec, Reliability of removal of selected pollutants in different technological solutions of household wastewater treatment plants. J. Water Land Dev. 35 (2017) 141148.

[20] A. Jucherski, A. Walczowski, P. Bugajski, K. Jóźwiakowski, Technological reliability of domestic wastewater purification in a small Sequencing Batch Biofilm Reactor (SBBR). Sep. Purif. Technol. 224 (2019) 340-347.

[21] B. Jawecki, J. Marszałek, K. Pawęska, M. Sobota, B. Malczewska, Construction and operation of domestic wastewater treatment plant under the relevant legislation. Part 2. Infrastructure and Ecology of Rural Areas II/2 (2016) 501-516 (in Polish).

[22] P. Bugajski, G. Kaczor, Evaluation of operation of some domestic sewage treatment plants under winter and summer conditions. Przemysł Chemiczny 87 (5) (2008) 44-426.

[23] J. Vymazal, The use constructed wetlands with horizontal sub-surface flow for various types of wastewater, Ecol. Eng. 35 (2009) 1-17.

[24] J. Vymazal, Constructed wetlands for wastewater treatment. Water 2 (3) (2010) 530-549.

[25] J. Vymazal. Constructed wetlands for wastewater treatment: Five decades of experience. Environ. Sci. Technol. 45 (2011) 61-69.

[26] M. Gajewska, H. Obarska-Pempkowiak, 20 years of experience of hybrid constructed wetlands exploitation in Poland. Rocznik Ochrony Środowiska 11 (2009) 875-888 (in Polish).

[27] J. Vymazal, Horizontal sub-surface flow and hybrid constructed wetlands systems for wastewater treatment. Ecol. Eng. 25 (5) (2005) 478-490.

[28] A. Albuquerque, M. Arendacz, M. Gajewska, H. Obarska-Pempkowiak, P. Randerson, P. Kowalik, Removal of organic matter and nitrogen in an horizontal subsurface flow (HSSF) constructed wetland under transient loads. Water Sci. Technol. 60 (7) (2009) 1677-1682.

[29] M. Gajewska, K. Jóźwiakowski, A. Ghrabi, F. Masi, Impact of influent wastewater quality on nitrogen removal rates in multistage treatment wetlands. Environ. Sci. Pollut. Res. 22, (2015) 12840-1284. 
[30] Z. Mucha, W. Wójcik, K. Jóźwiakowski, M. Gajewska, Long-term operation of Kickuthtype constructed wetland applied to municipal wastewater treatment in temperate climate. Environ. Technol. 39 (9) (2018) 1133-1143.

[31] Y. Wen, C. Xu, G. Liu, Y. Chen, Q. Zhou, Enhanced nitrogen removal reliability and efficiency in integrated constructed wetland microcosms using zeolite. Front. Environ. Sci. En. 6 (1) (2012) 140-147.

[32] Y. Alfiya, A. Gross, M. Sklarz, E. Friedler, Reliability of on-site greywater treatment systems in Mediterranean and arid environments - a case study. Water Sci. Technol. 67 (6) (2013) 1389-1395.

[33] M. Garfí, A. Pedescoll, J. Carretero, J. Puigagut, J. García, Reliability and economic feasibility of online monitoring of constructed wetlands performance. Desalin. Water Treat. 52 (31-33) (2014) 5848-5855.

[34] M. P. Alderson, A.B. Dos Santos, C.R. Mota Filho, Reliability analysis of low-cost, fullscale domestic wastewater treatment plants for reuse in aquaculture and agriculture. Ecol. Eng. 82 (2015) 6-14.

[35] A. Thomas, R.J. Morrison, P. Gangaiya, A.G. Miskiewicz, R.L. Chambers, M. Powell, Constructed wetlands as urban water constructed wetlands as urban water quality control ponds - studies on reliability and effectiveness. Wetlands Australia Journal 28 (1) (2016) 2-14.

[36] A. Jucherski, M. Nastawny, A. Walczowski, K. Jóźwiakowski, M. Gajewska, Assessment of the technological reliability of a hybrid constructed wetland for wastewater treatment in a mountain eco-tourist farm in Poland. Water Sci. Technol. 75 (11) (2017) 2649-2658.

[37] K. Jóźwiakowski, P. Bugajski, Z. Mucha, W. Wójcik, A. Jucherski, M. Natawny, T. Siwiec, T., A. Mazur, R. Obroślak, M. Gajewska, Reliability of pollutions removal processes during long-term operation of one-stage constructed wetland with horizontal flow. Sep. Purif. Technol. 187 (2017) 60-66.

[38] K. Jóźwiakowski, P. Bugajski, K. Kurek, M.F. Nunes de Carvalho, M.A. Araújo Almeida, T. Siwiec, G. Borowski, W. Czekała, J. Dach, M. Gajewska, The efficiency and technological reliability of biogenic compounds removal during long-term operation of a one-stage subsurface horizontal flow constructed wetland. Sep. Purif. Technol. 202 (2018) 216-226.

[39] E. Wojciechowska, M. Gajewska, A. Ostojski, Reliability of nitrogen removal processes in multistage treatment wetlands receiving high-strength wastewater. Ecol. Eng. 98 (2017) 365-371.

[40] R. Cáceres, E. Pol, L. Narváez, A. Puerta, O. Marfà, Web app for real-time monitoring of the performance of constructed wetlands treating horticultural leachates. Agric. Water Manag. (2017) 183, 177-185.

[41] K.L. Perttu, Biomass production and nutrient removal from municipal wastes using willow vegetation filters, J. Sustain. For. 1 (3) (1994) 57-70.

[42] K.L. Perttu, P.J. Kowalik, Salix vegetation filters for purification of waters and soils, Biomass Bioenergy 12 (1) (1997) 9-19.

[43] M. Gizińska-Górna, W. Czekała, K. Jóźwiakowski, A. Lewicki, J. Dach, M. Marzec, A. Pytka, D. Janczak, A. Kowalczyk-Juśko, A. Listosz, The possibility of using plants from 
hybrid constructed wetland wastewater treatment plants for energy purposes, Ecol. Eng. 95 (2006) 534-541.

[44] PN-EN 12566-3: 2016-10. Small wastewater treatment plants for a calculated population (CP) up to 50 - Part 3: Container and / or home on-site sewage treatment plants (in Polish). [45] Water Law of July 20, 2017. (Journal of Laws, August 23, 2017, item 1566) (in Polish).

[46] K. Jóźwiakowski, Studies on the efficiency of sewage treatment in chosen constructed wetland systems. Infrastructure and Ecology of Rural Areas 1 (2012) p. 232 (in Polish).

[47] EKO-GEO 2004. Environmental protection program for the Lublin poviat. Laboratory of Geology and Environmental Protection in Lublin, 127 (in Polish).

[48] T. Siwiec, L. Kiedryńska, K. Abramowicz, A. Rewicka, Analysis of chosen models describing the changes in $\mathrm{BOD}_{5}$ in sewages. Environ. Prot. Eng. 38 (2) (2012) 61-76.

[49] APHA, (American Public Health Association), Standard Methods For Examination of Water And Wastewater. 18th Edition, American Public Health Association (1992) Washington, DC.

[50] APHA, (American Public Health Association), Standard Methods for Examination of Water and Wastewater. 21st edition, American Public Health Association (2005) Washington, DC.

[51] Polish standards according limits for discharged sewage and environmental protection from July, 24 (2006) (No 137 item 984) and January, 28 (2009) (No 27 item 169) and November, 18 (2014) (No 2014 item 1800) (in Polish).

[52] P. Bugajski, Analysis of reliability of the treatment plant Bioblok PS-50 using the method of Weibull. Infrastrukture and Ecology of Rural Areas II (3) (2014) 667-677 (in Polish).

[53] J. Mucha 1994. Geostatistical methods in documenting deposits. Script, Department of Mine Geology. AGH Kraków, p. 155 (in Polish).

[54] CSO 1998-2011. Statistical yearbooks of environmental protection. Warszawa (in Polish).

[55] K. Chmielowski, P. Bugajski, Effectiveness of pollution removal in septic tanks of the "DUOFILTER" type. Infrastructure and Ecology of Rural Areas 5 (2008) 41-49 (in Polish).

[56] M. Keegan, K. Kilroy, D. Nolan, D. Dubber, P.M. Johnston, B.D.R. Misstear, V. O'Flaherty, M. Barrett, L.W. Gill, Assessment of the impact of traditional septic tank soakaway systems on water quality in Ireland. Water Sci. Technol. 70 (4) (2014) 634641.

[57] M. Gizińska-Górna, M. Marzec, K. Jóźwiakowski, A. Pytka, B. Sosnowska, A. Malik, A. Marczuk, J. Zarajczyk, M. Szmigielski, A. Grzywna, Impact of chambers number of primary settling tank on the chemical and microbiological pollution removal from wastewater. Przemysł Chemiczny 11 (2015) 1958-1962 (in Polish).

[58] M. Gajewska, H. Obarska-Pempkowiak, Nitrogen pathways during sewage treatment in constructed wetlands in temporary climate. In: Pawłowski L., Dudzińska M., Pawłowski A.(Eds.): Environmental Engineering. Taylor \& Francis Group (BALKEMA Proceedings and Monographs in Engineering, Water and Earth Sciences), London (2007) 71-79.

[59] A. Jucherski, M. Nastawny, A. Walczowski, K. Jóźwiakowski, M. Gajewska, Suitability studies of alkaline filtration materials for phosphates removal from biologically treated domestic sewage, Ochrona Środowiska 39 (1) (2017) 33-38. 
[60] K. Jóźwiakowski, M. Gajewska, A. Pytka, M. Marzec, M. Gizińska-Górna, A. Jucherski, A Walczowski, M Nastawny, A. Kamińska, S. Baran, Influence of the particle size of carbonate-siliceous rock on the efficiency of phosphorous removal from domestic wastewater, Ecol. Eng. 98 (2017) 290-296.

[61] K. Jóźwiakowski, M Marzec, J. Fiedurek, A. Kamińska, M. Gajewska, E. Wojciechowska, W. Shubiao, J. Dach, A. Marczuk, A. Kowalczyk-Juśko, Application of $\mathrm{H}_{2} \mathrm{O}_{2}$ to optimize of ammonium removal from domestic wastewater. Sep. Purif. Technol. 173 (2007) 357363. 